\title{
Algoritma Apriori Untuk Penentuan Assosiasi Penjualan Barang
}

\author{
Calvin Ivan Wiryawan'); Didik Nugroho'); Yustina Retno Wahyu Utami ${ }^{3)}$ \\ 1)2)3)Program Studi Informatika, STMIK Sinar Nusantara \\ 1)16500084.calvin@sinus.ac.id;2)masdidikhoho@sinus.ac.id;3) yustina_retno@sinus.ac.id
}

\begin{abstract}
The increasing of selling basic needs make the company has to provide a lot of goods. The data will be growing up with increasing the transaction at Sari Bumi store. All this time, the selling basic needs at Sari Bumi Store unstructured well so that needed an application with produce important information that can decide marketing strategies. In this research, Apriori algorithm is used to determine association rules. This method was chosen because it is one of the classic data mining algorithms to look for patterns of relationships between one or more items in one dataset. A priori algorithms can help companies in developing marketing strategies. The result of this research is combination between 4 item set with a minimum support of $30 \%$ and minimum confidence of $60 \%$.
\end{abstract}

Keywords: sale, staple, apriori algorithm

\section{PENDAHULUAN}

Kebutuhan bahan pokok yang setiap harinya mengalami peningkatan penjualan, menuntut pedagang untuk menerapkan strategi yang bisa meningkatkan penjualan bahan pokok. Sering terjadinya kekosongan salah satu bahan pokok yang dibeli konsumen, merupakan salah satu faktor dari tidak tersedianya informasi tentang kebiasaan belanja konsumen. Kekosongan barang yang sering terjadi setiap bulannya seperti Beras C64 Kualitas 2, Beras C64 Kualitas 3, Gula Pasir dan Minyak Goreng.

Data penjualan bahan pokok di Toko Sari Bumi selama ini tidak tersusun dengan baik, masih menggunakan pembukuan dalam membuat laporan, sehingga diperluakan suatu aplikasi yang dapat memanfaatkan data-data tersebut untuk menghasilkan suatu informasi penting yang dapat menentukan strategi pemasaran. Salah satu cara dalam mengolah data-data tersebut adalah dengan menerapkan penggunaan Data Mining.

Algortima association rule yang digunakan dalam penelitian ini adalah algoritma apriori. Algoritma apriori termasuk jenis aturan asosiasi pada data mining Metode ini dipilih karena merupakan salah satu algoritma klasik data mining untuk mencari pola hubungan antar satu atau lebih item dalam satu dataset[1].

Adapun tujuan dari penelitian ini adalah adalah terciptanya sistem keterkaitan penjualan bahan pokok yang sering terjual di Toko Sari Bumi sehingga dapat mengetahui bahan pokok yang sering dibeli secara bersamaan dan manfaat dari perusahaan menyediakan informasi penjualan kombinasi barang yang dapat digunakan untuk penentuan strategi pemasaran.

\section{TINJAUAN PUSTAKA}

Data Mining didefinisikan sebagai ekstraksi informasi potensial, implisit dan tidak dikenal dari sekumpulan data. Data mining juga dikenal dengan Knowlegde Discovery in Database (KDD). Proses KDD melibatkan hasil proses data, kemudian mengubah hasilnya secara akurat menjadi informasi yang mudah dipahami [2].

Hypertext Preprocessor atau PHP adalah bahasa pemrograman yang berfungsi untuk membuat website dinamis maupun aplikasi web yang bersifat server-side. Bahasa pemrograman ini berbeda dengan HTML yang bersifat statis, melainkan dapat berinteraksi dengan database, file dan folder sehingga diperoleh konten yang dinamis [3].

Salah satu sistem manajemen database yang bersifat open source dan banyak digunakan saat ini adalah MySQL. Beberapa dukungan fitur MySQL adalah multithread, multi-user, dan SQL database management system (DBMS) [4].

Pemodelan Unified Modelling Language (UML) adalah salah satu standar bahasa pemodelan sistem digunakan di industri dalam mendefinisikan kebutuhan sistem, membuat analisis dan desain, serta memodelkan arsitektur dalam object oriented programmimg [5].

Penelitian mengenai penerapan algoritma apriori untuk pengelompokan barang di usaha 
retail karena volume transaksi penjualan setiap harinya semakin bertambah banyak. Volume data yang besar memunculkan masalah bagi perusahaan. Tujuan penelitian ini mengetahui pola penjualan produk yang sering dibeli bersamaan. Hasil penelitian berbentuk aplikasi yang bisa mengelompokkan data pembelian berdasarkan kecenderunganya muncul bersamaan dalam suatu transaksi dengan menggunakan algoritma apriori [6].

Penelitian mengenai implementasi data mining pada penjualan produk elektronik dengan algoritma apriori. Latar belakang masalah penelitian ini adalah adanya transaksi penjualan yang kian hari kian bertambah. Data transaksi tersebut dimungkinkan dapat dimanfaatkan dan tidak hanya berfungsi sebagai arsip bagi perusahaan. Tujuan riset ini untuk mengetahui pemanfaatan algoritma apriori untuk membantu pengembangan strategi pemasaran. Dari sistem yang dihasilkan diperoleh pola penjualan produk elektronik [7].

Penelitian mengenai implementasi data mining dengan metode algoritma apriori dalam menentukan pola pembelian obat. Latar belakang masalah ini adalah persaingan dunia bisnis, khususnya apotek, menuntut para pengembang untuk menerapkan strategi yang jitu sehingga penjualan obat meningkat. Salah satu solusinya dengan tetap tersediannya berbagai jenis obat yang dibutuhkan oleh konsumen. Tujuan riset ini untuk mengetahui obat apa saja yang biasa dibeli oleh konsumen. Hasil penelitianya adalah sistem yang dibangun untuk pemenuhan dalam penentuan pola pembelian obat dengan menggunakan bahasa pemrograman Visual Basic 6.0 [8].

Penelitian mengenai analisis penjualan barang menggunakan algoritma apriori pada supermarket sejahtera Lhoksumawe dilatarbelakangi adanya kegiatan operasional sehari-hari semakin bertambah. Volume data yang kian bertambah memberi peluang untuk pemanfaatan bagi kepentingan perusahaan. Tujuan studi ini adalah mencari pola hubungan antar barang yang dibeli oleh konsumen. Hasil studi ini berupa aturan asosiasi antar barang pada supermarket [9].

Penelitian ini mengenai implementasi apriori pada sistem persediaan obat. Permasalahan yang timbul dalam penelitian ini adalah adanya transaksi operasional seharihari yang semakin bertambah. Penumpukan data-data transaksi tersebut bila dibiarkan akanmenjadi lautan data dan menjadi sampah data. Riset ini dimaksudkan untuk membentuk pola kombinasi itemset dari data penjualan dan menghasilkan rules dengan association rules dari pola kombinasi itemset yang interesting. Hasil dari penelitian diuji dengan aplikasi Tanagra menghasilkan pola kombinasi itemset dan rules [10].

Salah satu algoritma klasik di data mining adalah algortima apriori. Algortima apriori bermanfaat untuk mempelajari aturan asosiasi, dan menemukan pola hubungan antar satu lebih item dalam dataset. Implementasi aturan asosiasi antara beberapa atribut sering disebut affinity analysis atau market basket analysis. Analisis asosiasi dalam data mining dimaksudkan untuk menemukan pola atau aturan suatu kombinasi item. Tahapan analisis asosiasi yang menarik minat bagi banyak peneliti agar menghasilkan algoritma yang efisien adalah tahap analisis pola frequensi tinggi (frequent pattern mining). Faktor yang mempengaruhi penting tidaknya suatu asosiasi dapat diketahui dengan dua tolak ukur, yaitu: support dan confidence. Support merupakan persentase kombinasi item dalam database, sedangkan confidence (nilai kepastian) ialah kuatnya hubungan antara item dalam aturan asosiasi [11].

1. Analisa Pola Frekuensi Tinggi dengan Algoritma Apriori

Tahap analisis pola ditujukan untuk mencari kombinasi item yang memenuhi syarat minimum dari nilai support dalam basis data. Nilai support sebuah item diperoleh dengan menggunakan rumus berikut [12]:

$\operatorname{Support}(A)=\frac{\text { jumlah traksaksi mengandung } A}{\text { total transaksi }} * 100 \%$

Untuk mengukur nilai support dari 2 item diperoleh dengan menggunakan rumus:

$\operatorname{Support}(A, B)=P(A \cap B)$

$\operatorname{Support}(A, B)=\frac{\sum \text { traksaksi mengandung A dan } B}{\sum \text { transaksi }} * 100 \%$

Untuk mengukur nilai support dari 3 item diperoleh dengan menggunakan rumus:

$\operatorname{Support}(A, B, C)=P(A \cap B \cap C)$

$\operatorname{Support}(A, B, C)=\frac{\sum \text { traksaksi mengandung A,Bdan } C}{\sum \text { transaksi }} * 100 \%$

Untuk mengukur nilai support dari 4 item diperoleh dengan menggunakan rumus:

$\operatorname{Support}(A, B, C, D)=P(A \cap B \cap C \cap D)$

$\operatorname{Support}(A, B, C, D)=\frac{\sum \text { traksaksi mengandung } A, B, C, D}{\sum \text { transaksi }} * 100 \%$

Untuk mengukur nilai support dari 5 item diperoleh dengan menggunakan rumus:

$\operatorname{Support}(A, B, C, D, E)=P(A \cap B \cap C \cap D \cap E)$ 
$\operatorname{Support}(A, B, C, D, E)=\frac{\sum \text { traksaksi mengandung } A, B, C, D, E}{\sum \text { transaksi }} * 100 \%$

\section{Pembentukan Aturan Asosiasi}

Tahap pembentukan aturan asosiasi dilakukan setelah diketahui semua pola pada frekuensi tinggi. Tahap ini mencari aturan asosiasi yang memenuhi syarat minimum untuk confidence dengan menghitung confidence aturan asosiatif $A \longrightarrow B$. Nilai confidence dari aturan $\mathrm{A} \longrightarrow \mathrm{B}$ diperoleh dengan rumus berikut [12]:

Confidence $=P(B \mid A)=\frac{\sum \text { traksaksi mengandung } A \text { dan } B}{\sum \text { transaksi mengandung } A} * 100 \%$

\section{METODE PENELITIAN}

Tahapan penelitian yang diterapkan dalam riset ini mencakup metode pengumpulan data dan analisa data. Pengumpulan data meliputi observasi, wawancara, dan studi pustaka. Perangkat keras yang digunakan sebagai berikut:

$\begin{array}{ll}\text { Processor : Intel Celeron } \\ \text { Memori } & : 2 \mathrm{~GB} \\ \text { VGA } & : 790 \mathrm{MB} \\ \text { Hardisk } & : 300 \mathrm{~GB} \\ \text { Monitor } & : 1366 \times 768 \text { piksel }\end{array}$

Sedangkan perangkat lunak yang digunakan seperti Sistem Operasi Windows 7, Adobe Dreamwaver, Notepad ++, Xampp, MySql, Adobe Photoshop, Google Chrome. Sistem pada Toko Sari Bumi menggunakan algoritma apriori dengan menggunakan program aplikasi PHP dan MySql.

\section{HASIL DAN PEMBAHASAN}

4.1 Daftar Bahan Pokok di Toko Sari Bumi

Berikut ini daftar bahan pokok yang dijual di toko sari bumi, dapat dilihat pada Tabel 1 .

Tabel 1. Keterangan Bahan Pokok

\begin{tabular}{|c|l|}
\hline No & \multicolumn{1}{|c|}{ Nama Barang } \\
\hline 1 & Beras Mentik (BM) \\
\hline 2 & Beras Ketan (BK) \\
\hline 3 & Beras C64 Kualitas 1 (BC641) \\
\hline 4 & Beras C64 Kualitas 2 (BC642) \\
\hline 5 & Beras C64 Kualitas 3 (BC643) \\
\hline 6 & Beras C64 Kualitas 4 (BC644) \\
\hline 7 & Beras C64 Kualitas 5 (BC645) \\
\hline 8 & Gula Pasir TM (GP) \\
\hline 9 & Teh Balap (TB) \\
\hline 10 & Teh Gardoe Biru (TGB) \\
\hline 11 & Teh Gardoe ljo (TGI) \\
\hline 12 & Teh Dandang (TD) \\
\hline 13 & Teh Sapu (TS) \\
\hline 14 & Teh Sinten (TSI) \\
\hline 15 & Teh Gopek (TG) \\
\hline
\end{tabular}

\begin{tabular}{|c|l|}
\hline No & \multicolumn{1}{|c|}{ Nama Barang } \\
\hline 16 & Teh Djangoet (TDJ) \\
\hline 17 & Minyak Goreng (MG) \\
\hline
\end{tabular}

\subsection{Pola Transaksi Penjualan Bahan} Pokok pada Toko Sari Bumi

Transaksi penjualan bahan pokok di Toko Sari Bumi tersebut diakumulasikan. Akumulasi transaksi penjualan di Toko Sari Bumi diperoleh dari data penjualan bulanan yang memenuhi nilai minimum support bulanan 30\% diperlihatkan pada Tabel 2.

Tabel 2. Pola Transaksi Penjualan Bahan Pokok

\begin{tabular}{|r|l|}
\hline No & \multicolumn{1}{|c|}{ Item Set } \\
\hline 1 & BC641, BC642, BC643, MG, GP \\
\hline 2 & $\begin{array}{l}\text { BM, BC641, BC642, BC643, BC644, } \\
\text { GP. TD TSI }\end{array}$ \\
\hline 3 & $\begin{array}{l}\text { BK, BC641, BC642, BC643, BC645, } \\
\text { GP. MG }\end{array}$ \\
\hline 4 & BC641, BC643, BC644, BC645, TD \\
\hline 5 & BC641, BC642, BC643, BC645, TD, MG \\
\hline 6 & BC642, BC645, TGI, TD, TSI \\
\hline 7 & $\begin{array}{l}\text { BC641, BC642, BC643, BC645, TD, } \\
\text { GP, MG }\end{array}$ \\
\hline 8 & BM, BC642, BC643, BC644, MG \\
\hline 9 & $\begin{array}{l}\text { BM, BK, BC641, BC642, BC644, GP, } \\
\text { TG MG }\end{array}$ \\
\hline 10 & BM, BC643, GP, TG, MG \\
\hline 11 & $\begin{array}{l}\text { BM, BC641, BC642, BC644, BC645, } \\
\text { GP, MG }\end{array}$ \\
\hline 12 & $\begin{array}{l}\text { BM, BC641, BC642, BC645, GP, TB, } \\
\text { TD, TS, MG }\end{array}$ \\
\hline
\end{tabular}

\section{a. Pembentukan 1 itemset}

Pembentukan 1 itemset berdasarkan data yang sudah diperlihatkan pada Tabel 2 . Proses pembentukan 1 itemset dengan minimal support $30 \%$ menggunakan rumus 1 , hasil ditampilkan di Tabel 3.

Tabel 3. Support dari tiap item

\begin{tabular}{|l|c|}
\hline \multicolumn{1}{|c|}{ Itemset } & Support \\
\hline BM & $50 \%$ \\
\hline BK & $16,67 \%$ \\
\hline BC641 & $75 \%$ \\
\hline BC642 & $83,33 \%$ \\
\hline BC643 & $66,67 \%$ \\
\hline BC644 & $41,67 \%$ \\
\hline BC645 & 58,33 \\
\hline GP & $66,67 \%$ \\
\hline TB & $8,3 \%$ \\
\hline TGI & $8,3 \%$ \\
\hline TD & $50 \%$ \\
\hline TS & $8,3 \%$ \\
\hline TSI & $16,67 \%$ \\
\hline TG & $16,67 \%$ \\
\hline MG & $75 \%$ \\
\hline
\end{tabular}




\section{b. Kombinasi 2 itemset}

Proses pembentukan 2 itemset dengan minimal support 30\% menggunakan rumus 2 .

Tabel 4. Support dari 2 itemset

\begin{tabular}{|l|c|c|}
\hline \multicolumn{1}{|c|}{ Itemset } & Jumlah & Support \\
\hline BM, BC642 & 5 & $41,67 \%$ \\
\hline BM, BC644 & 4 & $33,33 \%$ \\
\hline BM, GP & 5 & $41,67 \%$ \\
\hline BM, MG & 5 & $41,67 \%$ \\
\hline BC641, BC642 & 8 & $66,67 \%$ \\
\hline BC641, BC643 & 6 & $50 \%$ \\
\hline BC641, BC644 & 4 & $33,33 \%$ \\
\hline BC641, BC645 & 6 & $50 \%$ \\
\hline BC641,GP & 7 & $58,33 \%$ \\
\hline BC641, TD & 5 & $41,67 \%$ \\
\hline BC641, MG & 7 & $58,33 \%$ \\
\hline BC642, BC643 & 6 & $50 \%$ \\
\hline BC642, BC644 & 4 & $33,33 \%$ \\
\hline BC642, BC645 & 6 & $50 \%$ \\
\hline BC642,GP & 7 & $58,33 \%$ \\
\hline BC642,TD & 5 & $41,67 \%$ \\
\hline BC642, MG & 8 & $66,67 \%$ \\
\hline BC643, BC645 & 4 & $33,33 \%$ \\
\hline BC643, GP & 5 & $41,67 \%$ \\
\hline BC643,TD & 4 & $33,33 \%$ \\
\hline BC643,MG & 6 & $50 \%$ \\
\hline BC645,GP & 4 & $33,33 \%$ \\
\hline BC645,TD & 5 & $41,67 \%$ \\
\hline BC645,MG & 5 & $41,67 \%$ \\
\hline GP, MG & 7 & $58,33 \%$ \\
\hline
\end{tabular}

Minimal support yang tidak memenuhi akan dihilangkan. Dan nilai yang memenuhi nilai support akan dilanjutkan ke itemset berikutnya.

\section{c. Kombinasi 3 itemset}

Proses pembentukan 3 itemset dengan minimal support 30\% menggunakan rumus 3 .

Tabel 5. Support dari 3 itemset

\begin{tabular}{|l|c|c|}
\hline \multicolumn{1}{|c|}{ Itemset } & Jumlah & Support \\
\hline BM, BC642, BC644 & 4 & $33,33 \%$ \\
\hline BM, BC642, GP & 4 & $33,33 \%$ \\
\hline BM, BC642, MG & 4 & $33,33 \%$ \\
\hline BM, GP, MG & 4 & $33,33 \%$ \\
\hline BC641, BC642, BC643 & 4 & $33,33 \%$ \\
\hline BC641, BC642, BC645 & 5 & $41,67 \%$ \\
\hline BC641, BC642, GP & 7 & $58,33 \%$ \\
\hline BC641, BC642, TD & 4 & $33,33 \%$ \\
\hline BC641, BC642, MG & 7 & $58,33 \%$ \\
\hline BC641, BC643, BC645 & 4 & $33,33 \%$ \\
\hline BC641, BC643, MG & 4 & $33,33 \%$ \\
\hline BC641, BC645, GP & 4 & $33,33 \%$ \\
\hline BC641, BC645, TD & 4 & $33,33 \%$ \\
\hline BC641, BC645, MG & 4 & $33,33 \%$ \\
\hline BC641, GP, MG & 5 & $41,67 \%$ \\
\hline BC641, GP, TD & 4 & $33,33 \%$ \\
\hline
\end{tabular}

\begin{tabular}{|l|c|c|}
\hline Itemset & Jumlah & Support \\
\hline $\mathrm{BC641,} \mathrm{TD,} \mathrm{MG}$ & 4 & $33,33 \%$ \\
\hline $\mathrm{BC642,} \mathrm{GP,} \mathrm{MG}$ & 6 & $50 \%$ \\
\hline BC643, GP, MG & 4 & $33,33 \%$ \\
\hline BC645, GP, MG & 4 & $33,33 \%$ \\
\hline
\end{tabular}

Minimal support yang tidak memenuhi akan dihilangkan. Nilai yang memenuhi nilai support akan dilanjutkan ke itemset berikutnya

\section{d. Kombinasi 4 itemset}

Proses pembentukan 4 itemset dengan minimal support 30\% menggunakan rumus 4 .

Tabel 6. Support dari 4 itemset

\begin{tabular}{|l|c|c|}
\hline \multicolumn{1}{|c|}{ Itemse } & Jumlah & Support \\
\hline $\begin{array}{l}\text { BC641, BC642, BC643, } \\
\text { GP }\end{array}$ & 4 & $33,33 \%$ \\
\hline $\begin{array}{l}\text { BC641, BC642, BC643, } \\
\text { MG }\end{array}$ & 4 & $33,33 \%$ \\
\hline $\begin{array}{l}\text { BC641, BC643, BC645, } \\
\text { MG }\end{array}$ & 5 & $33,33 \%$ \\
\hline
\end{tabular}

Minimal support yang tidak memenuhi akan dihilangkan. Dan nilai yang memenuhi nilai support akan dilanjutkan ke itemset berikutnya.

\section{e. Kombinasi 5 itemset}

Proses pembentukan 5 itemset dengan minimal support $30 \%$ menggunakan rumus 5

Tabel 7. Kombinasi 5 itemset

\begin{tabular}{|l|c|c|}
\hline \multicolumn{1}{|c|}{ Itemset } & Jumlah & Support \\
\hline $\begin{array}{l}\text { BC641, BC642, BC643, } \\
\text { BC645, MG }\end{array}$ & 3 & $25 \%$ \\
\hline $\begin{array}{l}\text { BC641, BC642, BC643, } \\
\text { BC645, GP }\end{array}$ & 2 & $16,67 \%$ \\
\hline
\end{tabular}

Berdasarkan hasil kombinasi 5 itemset pada Tabel 7 , tidak ada yang memenuhi nilai support $30 \%$. Dengan demikian hasil yang digunakan untuk pembentukan aturan asosiasi adalah kombinasi 4 itemset.

\subsection{Pembentukan Aturan Asosiasi}

Tahap ini dilakukan setelah ditemukan semua pola frekuensi tinggi. Pembentukan aturan asosiasi yang memenuhi syarat minimum untuk confidence dengan menghitung confidence aturan asosiatif $A$ $\longrightarrow$ B. Nilai confidence dari aturan A $\longrightarrow$ B diperoleh dengan rumus 6 . Setelah kombinasi 4 itemset ditentukan, maka didapat nilai support dan confidence yang diperlihatkan pada Tabel 8.

Tabel 8. Pembentukan aturan asosiasi 


\begin{tabular}{|l|c|c|}
\hline \multicolumn{1}{|c|}{ Aturan } & \multicolumn{2}{|c|}{ Confidence } \\
\hline $\begin{array}{l}\text { If Buy BC641, BC642, BC643 } \\
\text { Then buy GP }\end{array}$ & $4 / 9$ & $44,44 \%$ \\
\hline $\begin{array}{l}\text { If Buy, BC642, BC643, GP } \\
\text { Then buy BC641 }\end{array}$ & $4 / 10$ & $40 \%$ \\
\hline $\begin{array}{l}\text { If Buy, BC643, GP, BC641 } \\
\text { Then buy BC642 }\end{array}$ & $4 / 8$ & $50 \%$ \\
\hline $\begin{array}{l}\text { If Buy GP, BC641, BC642, } \\
\text { Then buy BC643 }\end{array}$ & $4 / 8$ & $50 \%$ \\
\hline $\begin{array}{l}\text { If Buy BC641, BC642, BC643 } \\
\text { Then buy MG }\end{array}$ & $4 / 9$ & $44,44 \%$ \\
\hline $\begin{array}{l}\text { If Buy, BC642, BC643, MG } \\
\text { Then buy BC641 }\end{array}$ & $4 / 10$ & $40 \%$ \\
\hline $\begin{array}{l}\text { If Buy, BC643, MG, BC641 } \\
\text { Then buy BC642 }\end{array}$ & $4 / 8$ & $50 \%$ \\
\hline $\begin{array}{l}\text { If Buy MG, BC641, BC642, } \\
\text { Then buy BC643 }\end{array}$ & $4 / 9$ & $44,44 \%$ \\
\hline $\begin{array}{l}\text { If Buy BC641, BC643, BC645 } \\
\text { Then buy MG }\end{array}$ & $5 / 9$ & $55,56 \%$ \\
\hline $\begin{array}{l}\text { If Buy BC643, BC645, MG } \\
\text { Then buy BC641 }\end{array}$ & $5 / 8$ & $62,5 \%$ \\
\hline $\begin{array}{l}\text { If Buy BC645, MG, BC641 } \\
\text { Then buy BC643 }\end{array}$ & $5 / 7$ & $71,42 \%$ \\
\hline $\begin{array}{l}\text { If Buy MG, BC641, BC643 } \\
\text { Then buy BC645 }\end{array}$ & $5 / 9$ & $55,56 \%$ \\
\hline
\end{tabular}

\section{Aturan Asosiasi Final}

Berdasarkan tabel calon aturan asosiasi, maka yang dapet memenuhi syarat minumum support $30 \%$ dan minimum confidence $60 \%$, dapat dilihat pada Tabel 9.

Tabel 9. Aturan Asosiasi Final

\begin{tabular}{|l|c|c|}
\hline \multicolumn{1}{|c|}{ Aturan } & Support & Confidence \\
\hline $\begin{array}{l}\text { If Buy BC643, BC645, } \\
\text { MG Then buy BC641 }\end{array}$ & $33,33 \%$ & $62,5 \%$ \\
\hline $\begin{array}{l}\text { If Buy BC645, MG, } \\
\text { BC641 Then buy } \\
\text { BC643 }\end{array}$ & $33,33 \%$ & $71,42 \%$ \\
\hline
\end{tabular}

Jadi berdasarkan tabel aturan asosiasi final diatas, bahan pokok yang paling sering terjual adalah Beras C64 Kualitas 5, Minyak Goreng, Beras C64 Kualitas 1 dan Beras C64 Kualitas 3, sehingga Toko Sari Bumi dapat mengetahui bahan pokok yang sering dibeli secara bersamaan.

\subsection{Perancangan Sistem}

\section{a. Use Case Diagram}

Pemodelan dengan Use Case Diagram untuk menggambarkan hubungan fungsionalitas dari sistem dengan aktor internal/eksternal dari sistem dan aktor siapa saja yang dapat menggunakan kegiatankegiatan tersebut. Use case diagram
Penentuan Assosiasi Penjualan Barang Menggunakan Algoritma Apriori di Toko Sari Bumi diperlihatkan pada Gambar 1.

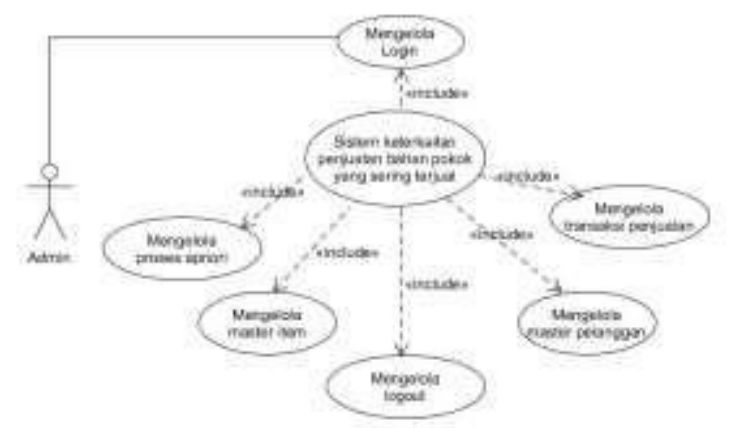

Gambar 1. Use case diagram

Admin/Administrator dapat melakukan pengolahan master item, mengelola master pelanggan, mengelola transaksi penjualan dan mengelola proses perhitungan apriori.

\section{b. Sequence Diagram}

1. Sequence diagram Administrator

Sequence diagram administrator aktifitas administrator masuk ke dalam halaman utama yang terdapat menu master item, transaksi data penjualan dan proses perhitungan apriori hingga logout. Sequence diagram ditunjukan pada Gambar 2.

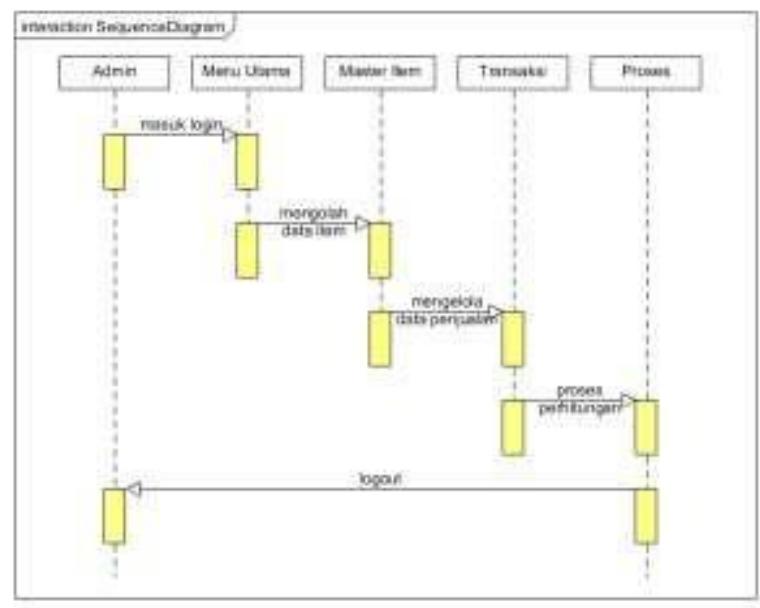

\section{Gambar 2. Sequence diagram activity administrator}

2. Sequence diagram Master Item

Bagian proses sequence diagram master item administrator memilih halaman utama untuk mengelola master item, kemudian pilih button tambah untuk menambahkan data item lalu mengisi kode item, nama item. Jika sudah selesai sistem akan mengirim atau memasukkan pada tabel master item seperti yang terlihat pada Gambar 3. 


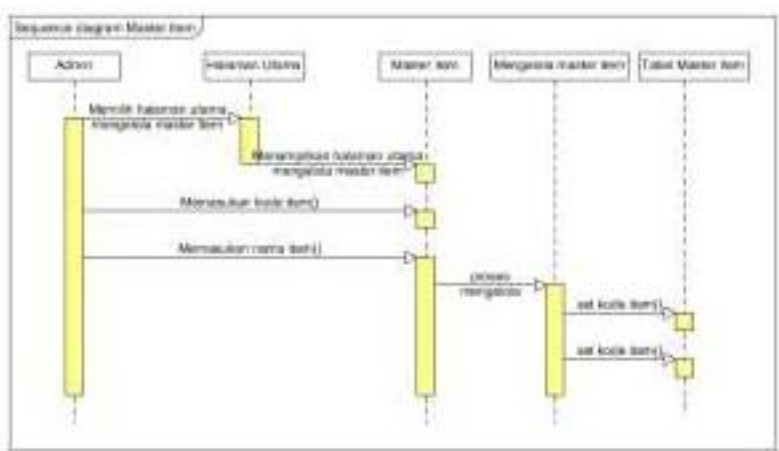

Gambar 3 Sequence diagram Master Item

3. Sequence diagram Master Pelanggan

Bagian proses sequence diagram master pelanggan administrator memilih halaman utama untuk mengelola master pelanggan, kemudian pilih button tambah untuk menambahkan data pelanggan lalu mengisi kode pelanggan, nama pelanggan, alamat, notlp. Jika sudah selesai sistem akan mengirim atau memasukkan pada tabel master pelanggan seperti yang terlihat pada Gambar 4.

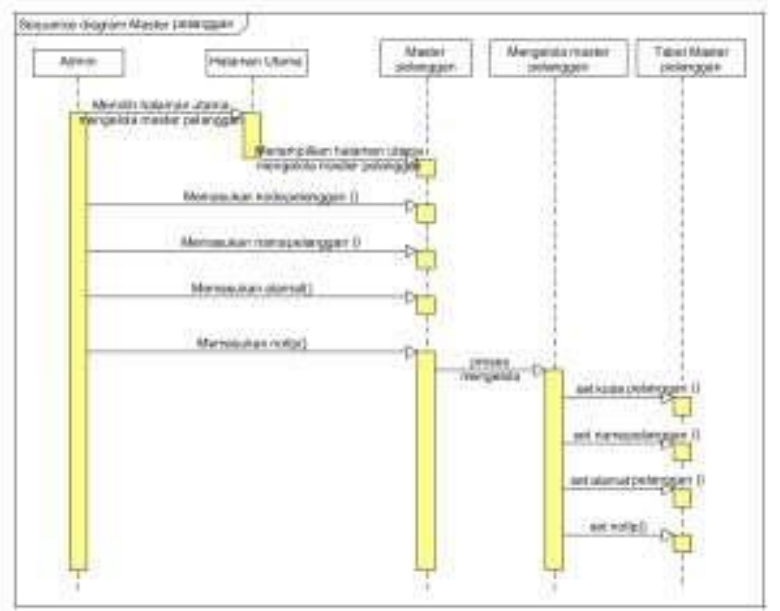

\section{Gambar 4 Sequence diagram Master Pelanggan}

4. Sequence diagram Transaksi Penjualan

Bagian proses sequence diagram transaksi penjualan administrator memilih halaman utama untuk mengelola transaksi penjualan, kemudian pilih import file untuk menambahkan data penjualan lalu klik import. Jika sudah selesai sistem akan memasukkan pada tabel transaksi penjualan seperti yang terlihat pada Gambar 5.

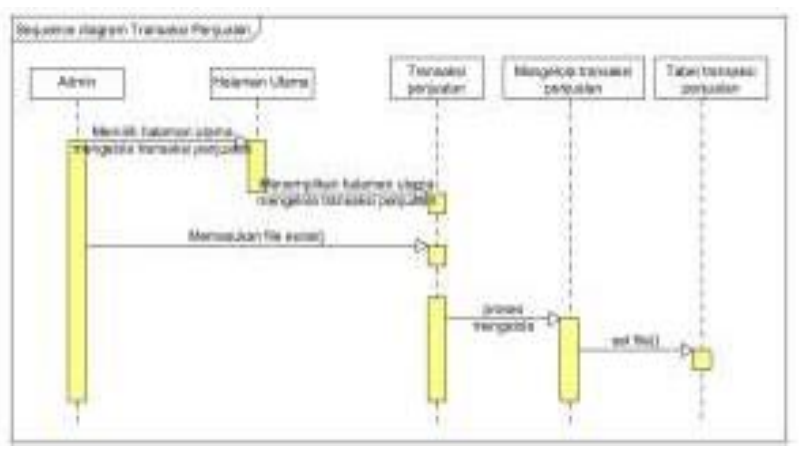

\section{Gambar 5 Sequence diagram transaksi} penjualan

5. Sequence diagram Logout

Bagian proses sequence diagram logout administrator memilih halaman utama dengan melakukan logout pada halaman utama, setelah itu admin akan keluar dari sistem dan sistem akan kembali ke halaman login seperti terlihat pada Gambar 6.

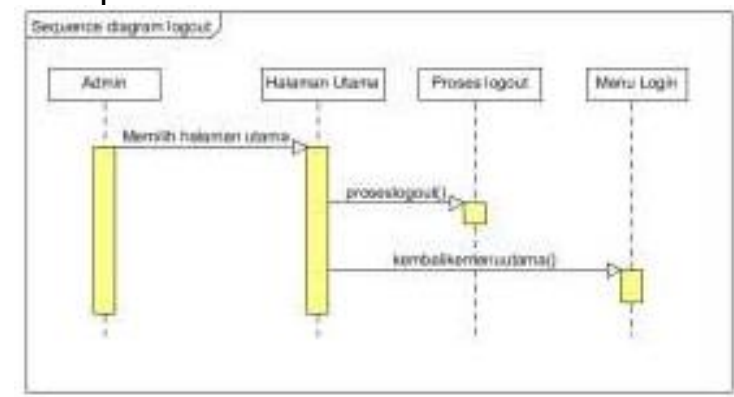

\section{Gambar 6 Sequence diagram Logout}

\section{c. Acitivity Diagram}

1. Activity diagram Administrator

Activity Diagram menggambarkan berbagai aliran aktivitas dari sebuah sistem, activity diagram digunakan untuk mendeskripsikan urutan aktivitas suatu system dan memperlihatkan alur dari satu aktivitas ke aktivitas lain. Aktivitas administrator dan sistem yang saling berkaitan ditunjukkan pada Gambar 7 .

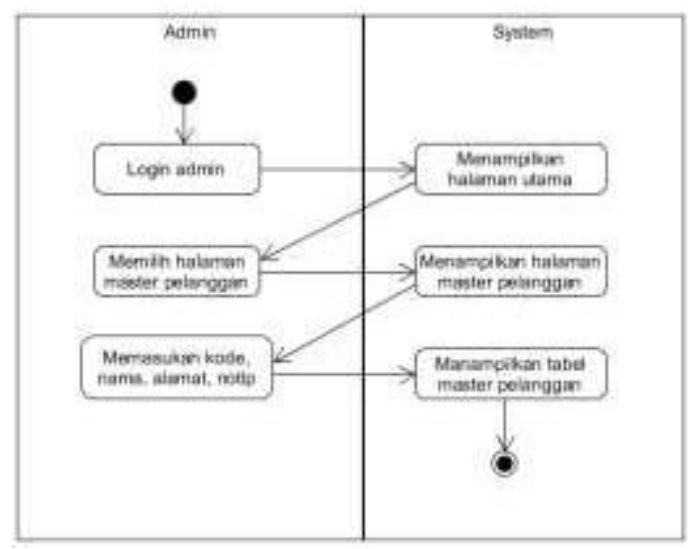




\section{Gambar 7 Activity Diagram Administrator}

\section{Activity diagram Master Item}

Seorang admin akan melakukan login kemudian sistem akan membawa admin pada halaman utama. Setelah tampil halaman utama keluar admin akan memilih menu master item. Setelah menampilkan halaman master item kemudian admin akan melakukan pengelolaan data item. Jika admin telah selesai menginputkan data, sistem akan menampilkan tabel data master item seperti pada gambar 8

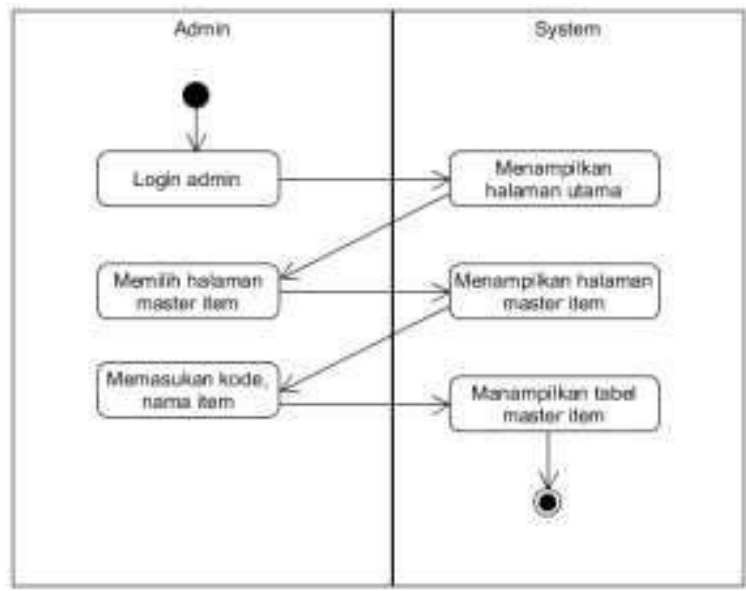

Gambar 8 Activity Diagram Master item

3. Activity diagram Master

Pelanggan Seorang admin akan melakukan login kemudian sistem akan membawa admin pada halaman utama. Setelah tampil halaman utama keluar, admin memilih menu master pelanggan. Setelah menampilkan halaman master pelanggan kemudian admin melakukan pengelolaan data pelanggan. Jika admin telah selesai menginputkan data, sistem akan menampilkan tabel data master pelanggan seperti pada Gambar 9.

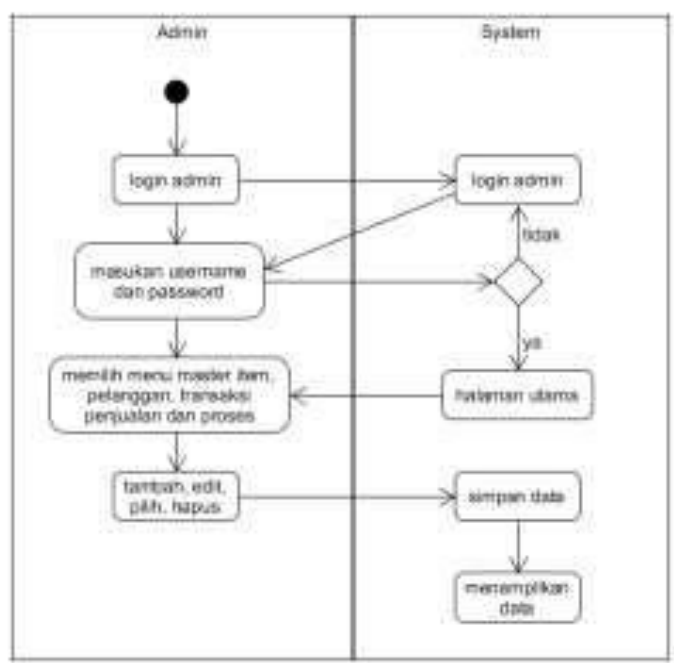

Gambar 9 Activity Diagram Master

\section{Pelanggan}

4. Activity diagram Transaksi Penjualan

Seorang admin akan melakukan login kemudian sistem akan membawa admin pada halaman utama. Setelah tampil halaman utama keluar admin akan memilih menu transaksi penjualan. Setelah menampilkan halaman transaksi penjualan, kemudian admin mengimport file excel data penjualan. Jika admin telah selesai mengimport file, sistem akan menampilkan tabel data transaksi penjualan seperti pada Gambar 10.

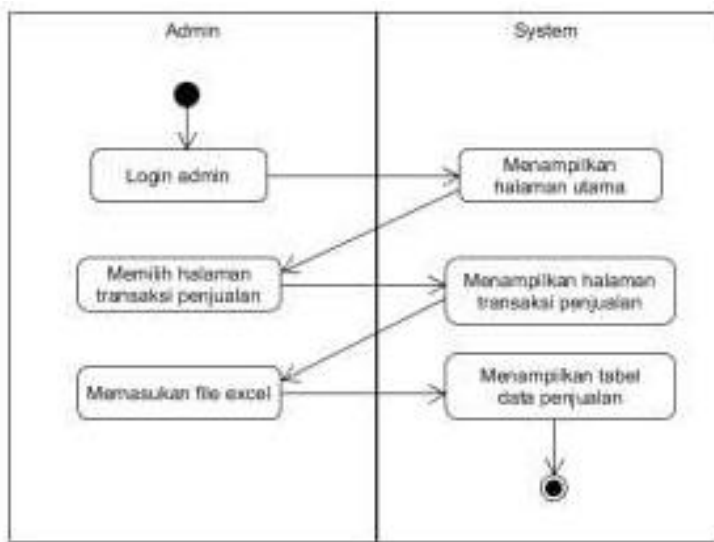

Gambar 10. Activity Diagram Transaksi penjualan

\section{Activity diagram Proses}

Seorang admin melakukan login kemudian sistem akan membawa admin pada halaman utama. Setelah tampil halaman utama keluar admin memilih menu proses. Setelah menampilkan halaman proses, kemudian admin menentukan tanggal, nilai minimum support dan nilai minimum confidence. Jika admin telah selesai menginputkan, sistem menampilkan aturan assosiasi seperti pada Gambar 11.

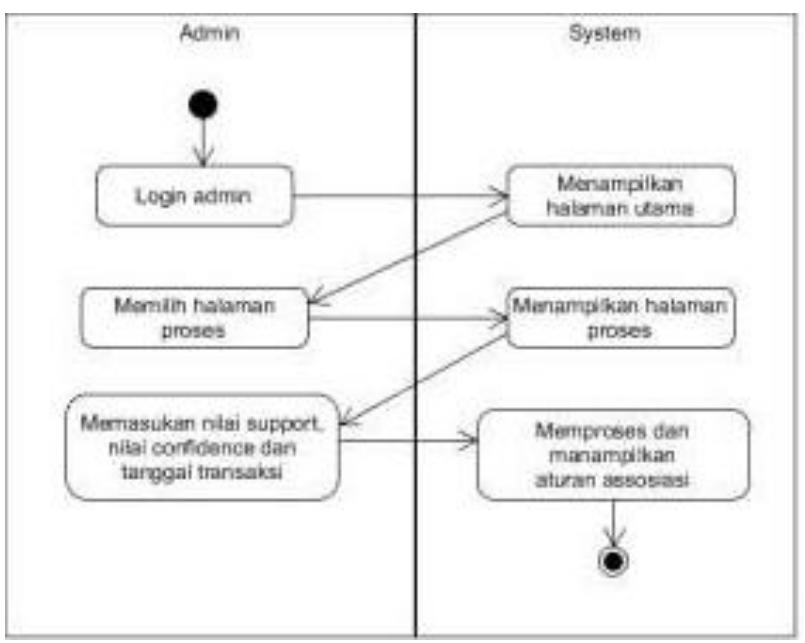




\section{Gambar 11. Activity Diagram Proses}

\section{Acitvity diagram Logout}

Seorang admin akan melakukan login kemudian sistem akan membawa admin pada halaman utama. Apabila admin menyetujui logout maka otomatis logout dan sistem akan kembali ke halaman login. Activity diagram seperti pada Gambar 12.

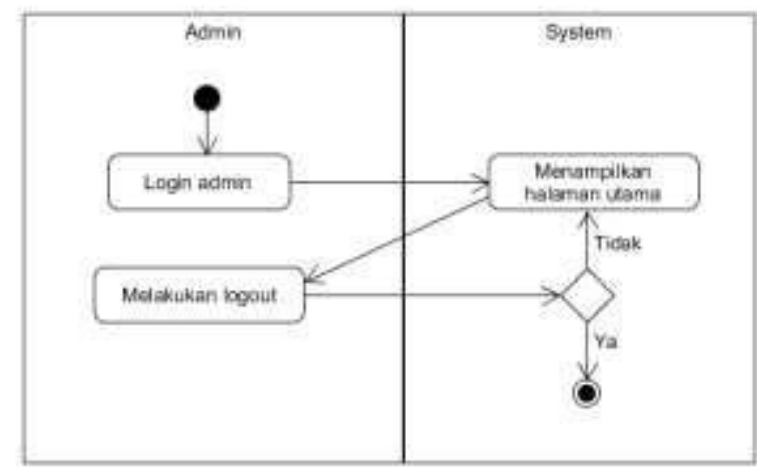

Gambar 12. Activity Diagram Logout

\section{d. Implementasi Sistem}

Sistem diimplementasikan dalam mengelola menu item, mengelola menu pelanggan, mengelola menu transaksi penjualan, dan menu perhitungan dengan menggunakan algoritma apriori. Di dalam menu item, user dapat menambahkan data item baru dengan cara klik tombol tambah kemudian menginputkan kode item dan nama barang baru yang akan dijual di Toko Sari Bumi setelah selesai klik save, Tampilan input item seperti pada Gambar 13.

\section{Tambah tien}

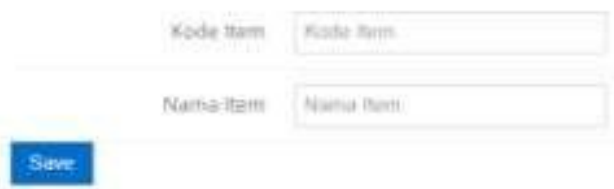

\section{Gambar 13. Tampilan input item}

Di dalam menu pelanggan, user dapat menambahkan data pelanggan baru dengan cara klik tombol tambah kemudian menginputkan kode pelanggan, nama pelanggan, alamat pelanggan dan no telepon pelanggan. Setelah selesai klik save. Tampilan input pelanggan seperti pada Gambar 14.
Tambah Pelangegan

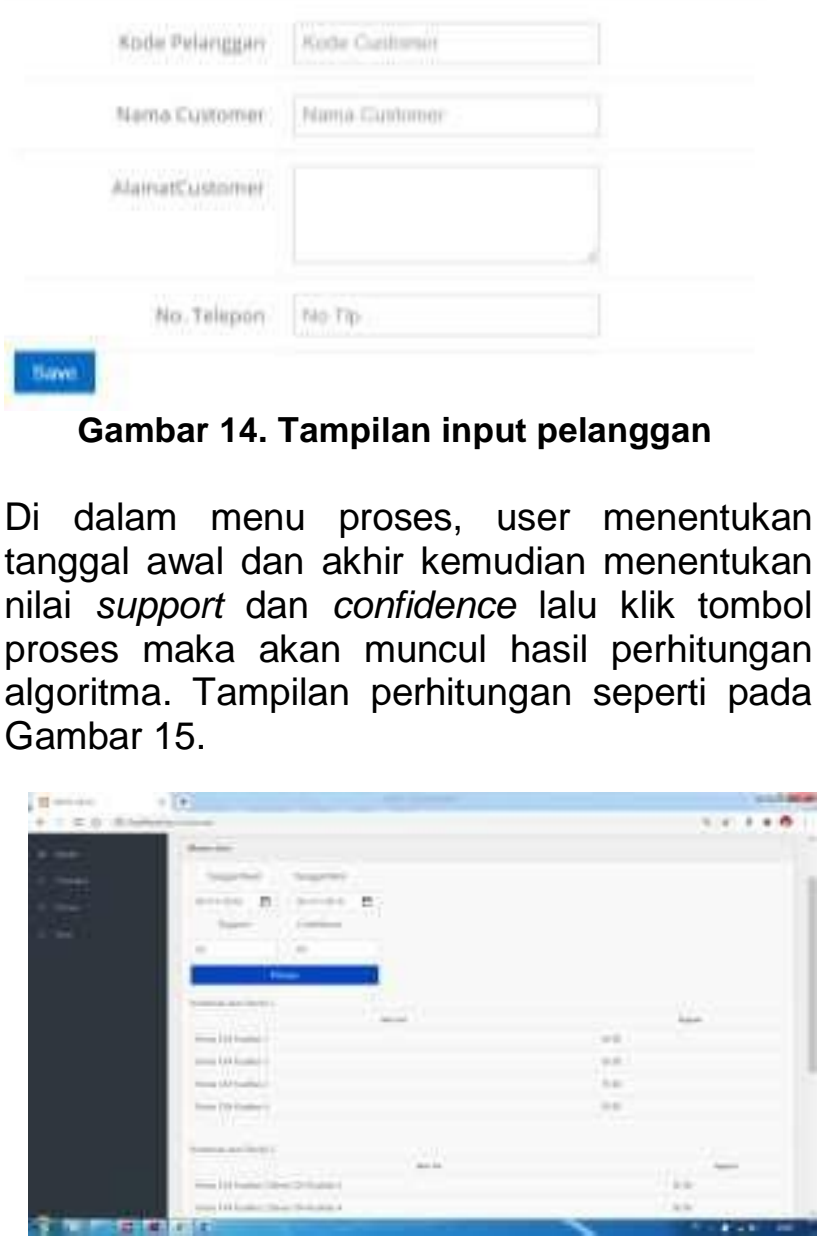

Gambar 15. Tampilan perhitungan

\section{e. Uji Validitas}

Pengujian program digunakan untuk mengetahui sistem pendukung keputusan valid atau tidak. Pengujian validitas dilakukan dengan menyiapkan data testing bulan MeiAgustus 2018 sebanyak 20 yang nilainya sama dengan Tabel 5 dan melihat hasil itemset yang lolos.

Uji validitas diperoleh dari pencarian error untuk selisih antara nilai rill dan nilai confidence. Nilai dianggap error jika selisih angka lebih dari $30 \%$. Nilai rill diperoleh dari jumlah kombinasi dibagi jumlah transaksi [13].

\section{Tabel 9 Nilai Riil}

\begin{tabular}{|l|l|l|l|l|}
\hline No & $\begin{array}{l}\text { Aturan } \\
\text { Kombinasi }\end{array}$ & $\begin{array}{l}\text { Jml Kom- } \\
\text { binasi }\end{array}$ & $\begin{array}{l}\text { Jml } \\
\text { Transaksi }\end{array}$ & $\begin{array}{l}\text { Nilai } \\
\text { Rill }\end{array}$ \\
\hline 1 & BC643, BC641 & 36 & 97 & $37,11 \%$ \\
\hline 2 & BC641, MG & 27 & 97 & $27,83 \%$ \\
\hline 3 & GP, BC643 & 34 & 97 & $35,05 \%$ \\
\hline 4 & MG, BC643 & 29 & 97 & $29,89 \%$ \\
\hline 5 & BM, BC641 & 22 & 97 & $22,68 \%$ \\
\hline
\end{tabular}




\begin{tabular}{|l|l|l|l|l|}
\hline No & $\begin{array}{l}\text { Aturan } \\
\text { Kombinasi }\end{array}$ & $\begin{array}{l}\text { Jml Kom- } \\
\text { binasi }\end{array}$ & $\begin{array}{l}\text { Jml } \\
\text { Transaksi }\end{array}$ & $\begin{array}{l}\text { Nilai } \\
\text { Rill }\end{array}$ \\
\hline 6 & BM, GP & 21 & 97 & $21,64 \%$ \\
\hline 7 & TD, BC641 & 28 & 97 & $28,86 \%$ \\
\hline 8 & TSI, BC642 & 18 & 97 & $18,55 \%$ \\
\hline 9 & BC644, GP & 29 & 97 & $29,89 \%$ \\
\hline 10 & BK, BC641 & 26 & 97 & $26,80 \%$ \\
\hline 11 & BC642, BC643 & 29 & 97 & $29,89 \%$ \\
\hline 12 & BC642, BC644 & 19 & 97 & $19,67 \%$ \\
\hline
\end{tabular}

aplikasi Tanagra dan sistem ditunjukan pada Tabel 11.

Tabel 11 Perbandingan Pengujian Sistem dengan Aplikasi Tanagra

\begin{tabular}{|c|c|c|c|c|}
\hline Kategori & Penguji & stem & Penguj & Tanagra \\
\hline $\begin{array}{c}1 \text { item- } \\
\text { set }\end{array}$ & $\begin{array}{l}\text { TDJ }= \\
30,9 \% \\
\text { TG }= \\
34 \% \\
\\
\text { TS }= \\
34 \% \\
\\
\text { BM }= \\
36,1 \% \\
\text { BK }= \\
37,1 \% \\
\\
\text { TD }= \\
39,2 \% \\
\text { GP }= \\
57,7 \%\end{array}$ & $\begin{array}{l}\text { MG }= \\
45,5 \% \\
\text { BC644 } \\
=45,4 \% \\
\text { BC642 } \\
=54,6 \% \\
\text { BC643 } \\
=58,8 \% \\
\text { BC641 } \\
=64,9 \% \\
B C 645 \\
=43,3 \%\end{array}$ & $\begin{array}{l}\text { TDJ }= \\
30,9 \% \\
\text { TG }= \\
34 \% \\
\text { TS }= \\
34 \% \\
\text { BM }= \\
36,1 \% \\
\text { BK }= \\
37,1 \% \\
\text { TD }= \\
39,2 \% \\
\text { GP }= \\
57,7 \%\end{array}$ & $\begin{array}{l}\mathrm{MG}= \\
45,5 \% \\
\text { BC644 } \\
=45,4 \% \\
\text { BC642 } \\
=54,6 \% \\
\text { BC643 } \\
=58,8 \% \\
\text { BC641 } \\
=64,9 \% \\
\text { BC645 } \\
=43,3 \%\end{array}$ \\
\hline $\begin{array}{c}2 \text { item- } \\
\text { set }\end{array}$ & $\begin{array}{l}\text { GP dan } \\
35,1 \% \\
\text { GP dan } \\
33,0 \% \\
\text { BC643 } \\
=37,1 \% \\
\text { BC642 } \\
=30,9 \% \\
\text { BC642 } \\
30 \% \\
\text { BC644 } \\
30 \% \\
\text { MG dar } \\
30 \%\end{array}$ & $\begin{array}{l}643= \\
641= \\
B C 641 \\
B C 641 \\
\text { GP }= \\
\text { GP }= \\
643=\end{array}$ & $\begin{array}{l}\text { GP dan } \\
=35,1 \% \\
\text { GP dan } \\
=33,0 \% \\
\text { BC643 } \\
\text { BC641 } \\
\text { BC642 } \\
\text { BC641 } \\
\text { BC642 } \\
=30 \% \\
\text { BC644 } \\
=30 \% \\
\text { MG dar } \\
=30 \%\end{array}$ & $\begin{array}{l}3 \mathrm{C} 643 \\
3 \mathrm{C} 641 \\
\text { an } \\
37,1 \% \\
\text { an } \\
30,9 \% \\
\text { an GP } \\
\text { an GP } \\
\text { BC643 }\end{array}$ \\
\hline $\begin{array}{l}\text { Aturan } \\
\text { Asosia } \\
\text { si Final }\end{array}$ & $\begin{array}{l}\text { Jika me } \\
\text { BC644 } \\
30 \% \text { ak } \\
\text { GP den } \\
\text { hubung }\end{array}$ & $\begin{array}{l}\text { eeli Beras } \\
\text { mungkinan } \\
\text { membeli } \\
\mathrm{n} \text { tingkat } \\
65,90 \%\end{array}$ & $\begin{array}{l}\text { Jika m€ } \\
\text { Beras } \mathrm{E} \\
\text { kemuns } \\
\text { akan } m \\
\text { dengan } \\
\text { hubung }\end{array}$ & $\begin{array}{l}\text { nbeli } \\
\text { k644 } \\
\text { inan 30\% } \\
\text { mbeli GP } \\
\text { ingkat } \\
\text { n 65,90\% }\end{array}$ \\
\hline $\begin{array}{l}\text { Aturan } \\
\text { Asosias } \\
\text { i Final }\end{array}$ & $\begin{array}{l}\text { Jika me } \\
\text { MG ken } \\
30 \% \text { ak } \\
\text { membe } \\
\text { dengan } \\
\text { hubung }\end{array}$ & $\begin{array}{l}\text { eli Beras } \\
\text { gkinan } \\
643 \\
643 \\
\text { kat } \\
5,90 \%\end{array}$ & $\begin{array}{l}\text { Jika me } \\
\text { Beras } 1 \\
\text { kemun } \\
30 \% \text { ak } \\
\text { membe } \\
\text { dengan } \\
\text { hubung }\end{array}$ & $\begin{array}{l}\text { ibeli } \\
\text { G } \\
\text { inan } \\
\text { n } \\
\text { BC643 } \\
\text { ingkat } \\
\text { n }\end{array}$ \\
\hline
\end{tabular}

Tabel 10 Hasil Pengujian Kombinasi 2

\begin{tabular}{|c|c|c|c|c|c|}
\hline No & $\begin{array}{l}\text { Aturan } \\
\text { Kombi } \\
\text { nasi }\end{array}$ & Nilai Riil & $\begin{array}{l}\text { Conf } \\
\text { idance } \\
\text { Sistem }\end{array}$ & Selisih & $\begin{array}{l}\text { Ketera } \\
\text { ngan }\end{array}$ \\
\hline 1 & $\begin{array}{l}\text { BC643, } \\
\text { BC641 }\end{array}$ & $37,11 \%$ & $\begin{array}{c}63,1 \\
5 \%\end{array}$ & $\begin{array}{c}26,0 \\
4 \%\end{array}$ & $\begin{array}{l}\text { Tidak } \\
\text { Sesuai }\end{array}$ \\
\hline 2 & $\begin{array}{l}\text { BC641, } \\
M G\end{array}$ & $27,83 \%$ & $\begin{array}{c}61,3 \\
6 \%\end{array}$ & $\begin{array}{c}33,5 \\
3 \%\end{array}$ & Sesuai \\
\hline 3 & $\begin{array}{l}\text { GP, } \\
\text { BC643 }\end{array}$ & $35,05 \%$ & $\begin{array}{c}60,7 \\
1 \% \\
\end{array}$ & $\begin{array}{c}25,6 \\
6 \% \\
\end{array}$ & $\begin{array}{l}\text { Tidak } \\
\text { Sesuai }\end{array}$ \\
\hline 4 & $\begin{array}{l}\text { MG, } \\
\text { BC643 }\end{array}$ & $29,89 \%$ & $\begin{array}{c}65,9 \\
0 \%\end{array}$ & $\begin{array}{c}36,0 \\
1 \%\end{array}$ & Sesuai \\
\hline 5 & $\begin{array}{l}\text { BM, } \\
\text { BC641 }\end{array}$ & $22,68 \%$ & $\begin{array}{c}62,8 \\
5 \% \\
\end{array}$ & $\begin{array}{c}40,1 \\
\% 7 \\
\end{array}$ & Sesuai \\
\hline 6 & $\begin{array}{l}\text { BM, } \\
\text { GP }\end{array}$ & $21,64 \%$ & $60 \%$ & $\begin{array}{c}38,3 \\
6 \%\end{array}$ & Sesuai \\
\hline 7 & $\begin{array}{l}\text { TD, } \\
\text { BC641 }\end{array}$ & $28,86 \%$ & $\begin{array}{c}73,6 \\
8 \%\end{array}$ & $\begin{array}{c}44,8 \\
2 \%\end{array}$ & Sesuai \\
\hline 8 & $\begin{array}{l}\text { TSI, } \\
\text { BC642 }\end{array}$ & $18,55 \%$ & $\begin{array}{c}62,0 \\
6 \%\end{array}$ & $\begin{array}{c}43,5 \\
1 \%\end{array}$ & Sesuai \\
\hline 9 & $\begin{array}{l}\text { BC644, } \\
\text { GP }\end{array}$ & $29,89 \%$ & $\begin{array}{c}65,9 \\
0 \%\end{array}$ & $\begin{array}{c}36,0 \\
1 \%\end{array}$ & Sesuai \\
\hline 10 & $\begin{array}{l}\text { BK, } \\
\text { BC641 }\end{array}$ & $26,80 \%$ & $\begin{array}{c}72,2 \\
2 \%\end{array}$ & $\begin{array}{c}45,4 \\
2 \%\end{array}$ & Sesuai \\
\hline 11 & $\begin{array}{l}\text { BC642, } \\
\text { BC643 }\end{array}$ & $29,89 \%$ & $67 \%$ & $\begin{array}{c}37,1 \\
1 \%\end{array}$ & Sesuai \\
\hline 12 & $\begin{array}{l}\text { BC642, } \\
\text { BC644 }\end{array}$ & $19,67 \%$ & $67 \%$ & $\begin{array}{c}47,3 \\
3 \% \\
\end{array}$ & Sesuai \\
\hline
\end{tabular}

Berdasarkan hasil pengujian pada Tabel 10, terdapat selisih nilai confidence. Selisih error berjumlah 2 dari 12 data dengan selisih $30 \%$, maka dihitung rata- ratanya yaitu $=$ $2 / 12=0,1667$ atau $16,67 \%$.

\section{f. Penggujian Menggunakan Aplikasi Tanagra}

Untuk membuktikan data-data yang telah dihasilkan berupa pola kombinasi itemset dan rules asosiasi sesuai dengan Algoritma Apriori maka perlu dilakukan pengujian menggunakan suatu aplikasi. Aplikasi yang digunakan adalah Tanagra versi 1.4.50.

Pengujian dengan menggunakan aplikasi Tanagra nantinya akan dibandingkan dengan hasil perhitungan dari sistem. Perbandingan 
Berdasarkan Tabel 11 diatas dapat disimpulkan hasil dari perhitungan sistem dan hasil dari rules dari aplikasi Tanagra menghasilkan nilai sama.

\section{PENUTUP}

\subsection{Kesimpulan}

Berdasarkan hasil penelitian, maka dapat diambil kesimpulan diantaranya sebagai berikut:

1. Dari data penjualan bulan Mei 2018 April 2019 dengan minimal support 30 $\%$ dan minimal confidence $60 \%$, nilai association rule kombinasi 4 itemset tertinggi adalah Beras C64 Kualitas 3, Beras C64 Kualitas 5, Minyak Goreng dan Beras C64 Kualitas 1 dengan nilai support $33,33 \%$ dan nilai confidence $62,5 \%$. Beras C64 Kualitas 5, Minyak Goreng, Beras C64 Kualitas 1, dan Beras C64 Kualitas 3 dengan nilai support $33,33 \%$ dan nilai confidence $71,42 \%$.

2. Hasil dari aplikasi ini, pemilik Toko Sari Bumi dapat mengetahui kombinasi pembelian bahan pokok yang sering dibeli secara bersamaan oleh pelanggan sehingga dapat meningkatkan penjualan dan keuntungan pada Toko Sari Bumi dengan uji validitas sistem yaitu $16,67 \%$.

\subsection{Saran}

Penelitian ini perlu pengembangan atau penyempurnaan sistem ini di masa yang akan datang. Untuk penelitian selanjutnya diharapkan penelitian selanjutnya dapat menggunakan metode Algoritma FP-Growth untuk membandingkan nilai akurasinya.

\section{DAFTAR PUSTAKA}

[1] S. Sundari, "Analisa Penerapan Datamining Pada Penjualan Produk Oli Mesin Sepeda Motor Dengan Algoritma Apriori," 2017.

[2] B. Tampubolon, Saragih, Reza, "Implementasi Data Mining Algoritma Apriori pada sistem persediaan alat-alat kesehatan," Inf. dan Teknol. IIm., vol. 1, no. 1, pp. 93-106, 2013.

[3] G. Agung P., HTML, PHP, dan MySQL untuk Pemula. Elex Media Komputindo, 2018.

[4] M. F. Mundzir, PHP tutorial book for beginner.Yogyakarta: Notebook, 2014.

[5] R.A. Sukamto dan M. Shalahuddin, Rekayasa Perangkat Lunak. Bandung: Informatika, 2013.

[6] M. Ikhsan, M. Dahria, and Sulindawati,
"Penerapan Associaton Rule dengan Algoritma Apriori Pada Proses Pengelompokan Barang di Perusahaan Retail," Pros. SNIKOM, 2013.

[7] D. K. Pane, "Implementasi Data Mining Pada Penjualan Produk Elektronik Dengan Algoritma Apriori (Studi Kasus: Kreditplus)," Pelita Inform. Budi Darma, vol. 4, no. 3, pp. 25-29, 2013.

[8] R. Yanto, Robi dan Khoiriah, "Implementasi Data Mining dengan Metode Algoritma Apriori dalam Menentukan Pola Pembelian Obat," Creat. Inf. Technol. J., vol. 2, no. 2, p. 102, 2015.

[9] N. A. Hasibuan et al., "Implementasi Data Mining Untuk Pengaturan Layout," vol. 4, no. 4, pp. 6-11, 2017.

[10] E. Buulolo, "Implementasi Algoritma Apriori Pada Sistem Persediaan Obat (Studi Kasus: Apotik Rumah Sakit Estomihi Medan)," Pelita Inform. Budi Darma, vol. IV, no. 1, pp. 71-83, 2013.

[11] D. Kusumo, Bijaksana, Darmantoro, "Data Mining Dengan Algoritma Apriori Pada Rdbms Oracle," TEKTRIKA - J. Penelit. dan Pengemb. Telekomun. Kendali, Komputer, Elektr. dan Elektron., vol. 8, no. 1, pp. 1-5, 2016.

[12] E. N. Sari, "Pakaian Yang Paling Diminati Pada Mode Fashion Group Medan," Pelita Inform. Budi Darma, vol. 4, no. 3, pp. 3539, 2013.

[13] H. Setiawan, M. Hasbi, and R. T. Vulandari, "Kombinasi pembelian makanan pada toko roti menggunakan algoritma apriori," J. IIm. Sinus, vol. 1, no. 2, pp. 3-9, 2019. 